\title{
MORPHOTECTONIC ANALYSIS IN THE ELIKI FAULT ZONE (GULF OF CORINTH, GREECE)
}

\author{
Verrios S., Zygouri V., and Kokkalas S. \\ Department of Geology, University of Patras, 26500,Patras, Greece, skokalas@upatras.gr
}

\begin{abstract}
Morphotectonic analysis using geomorphic indices has been developed as a basic reconnaissance tool in order to identify areas experiencing rapid tectonic deformation or estimate relative variations of tectonic activity in a specific area. We applied this analysis in Eliki fault zone, which is located in the western part of the Gulf of Corinth. Eliki fault zone was selected because it displays a spectacular geomorphic expression and hosts historic and recent seismicity. The intensity of active tectonics is interpreted through a detailed geomorphic study of the fault-generated mountain fronts and fluvial systems. Tectonic geomorphology analysis of the Eliki footwall area includes the application of the most commonly used geomorphic indices, such as the mountain front sinuosity index $(\mathrm{Smf})$, the valley floor / width ratio index (Vf), the stream gradient index (SL) and the transverse topographic symmetry factor $(T)$. These indices were estimated on topographic maps and aerial photographs of the study area in order to correlate active tectonics and erosional processes. Our results imply that the Eliki fault zone can be assigned to a tectonic class of the higher tectonic activity. However, spatial variations of tectonic activity along the segmented studied fronts point to a general trend of increasing activity towards the east, which is gradually decreasing towards the west.
\end{abstract}

\section{INTRODUCTION - GEOLOGICAL SETTING}

Evaluation of landforms produced and modified by active tectonics can provide basic data necessary for estimating long-term deformation and tectonic activity. The most characteristic landforms are the fault generated mountain fronts. Therefore, based on the geomorphologic analysis of mountain fronts, the related drainage networks and the calculation of several geomorphic indices in a specific area, we can retrieve valuable information about the recorded tectonic history.

The Aegean region is an area of active and rapid continental extension with high levels of seismicity recorded both historically and instrumentally (McKenzie 1978, Le Pichon \& Angelier 1981, Jackson \& McKenzie 1988, Papazachos \& Papazachou 1997, Ambrasseys \& Jackson 1997). Current rates of extension, which are geodetically determined across the Gulf of Corinth suggest that this region is one of the most rapidly extending continental areas in the world, with the highest deformation velocity observed at its western end (Clarke et al. 1997). This $\mathrm{N}-\mathrm{S}$ extension is accommodated by WNW- and ENE- trending, $10-40 \mathrm{Km}$ long normal faults in the upper crust (Fig. 1a; Jackson et al. 1982, King et al. 1985, Ambrasseys \&Jackson 1990, Doutsos \& Piper 1990, Jackson 1994, Roberts \& Koukouvelas 1996, Doutsos \& Kokkalas 2001). On the southern flank of the Gulf, between the Egion and Diakopto towns, there is a series of five major north facing almost $E-W$ trending normal faults (called Egion, Eliki, Keryneia, Melissia and Pyrgaki faults) which control the accumulation of sediments and the geomorphology within the westernmost end of the Gulf (Fig. 1b inset; Poulimenos \& Doutsos 1996, Koukouvelas 1998b). The $22 \mathrm{Km}$ long Eliki fault, which in fact is a segmented fault zone comprising smaller normal faults, is the most prominent fault scarp over the gulf (Doutsos \& Poulimenos 1992) and has hosted at least three major seismic events in the last 2000 years, as it is suggested by historical records and recent paleoseismological studies (Koukouvelas et al. 2001, Pavlides et al. 2004). It is divided by an almost $2 \mathrm{Km}$ long step-over zone into two prominent segments, the western with a length of $9 \mathrm{Km}$ and the eastern with a length of $13 \mathrm{Km}$ (Fig. 1c; Pavlides et al. 2004). To the east the Eliki fault scarp separates Neogene fan deltas and alluvial sediments while the western part comprises fluvial sediments in the hangingwall and Cretaceous 
limestones or Jurassic cherts in the footwall (Piper et al. 1990, Pavlides et al. 2004). The mountain front reaches an elevation that varies between $20 \mathrm{~m}$ in the east to more than $200 \mathrm{~m}$ in the west above the surrounding terrain (Fig. 1c). A narrow fault zone $\sim 100 \mathrm{~m}$ wide characterizes the west Eliki fault while at the eastern segment the zone is almost $400 \mathrm{~m}$ wide (Pavlides et al. 2004).

Aim of this study is to discriminate the geomorphic signals of the different fault segments on a faulted mountain front evolving under different range of uplift rates. The application of the most widely-known geomorphic indices in the Eliki fault zone enabled us to correlate active tectonics along this major fault zone with erosional processes in the broad area.

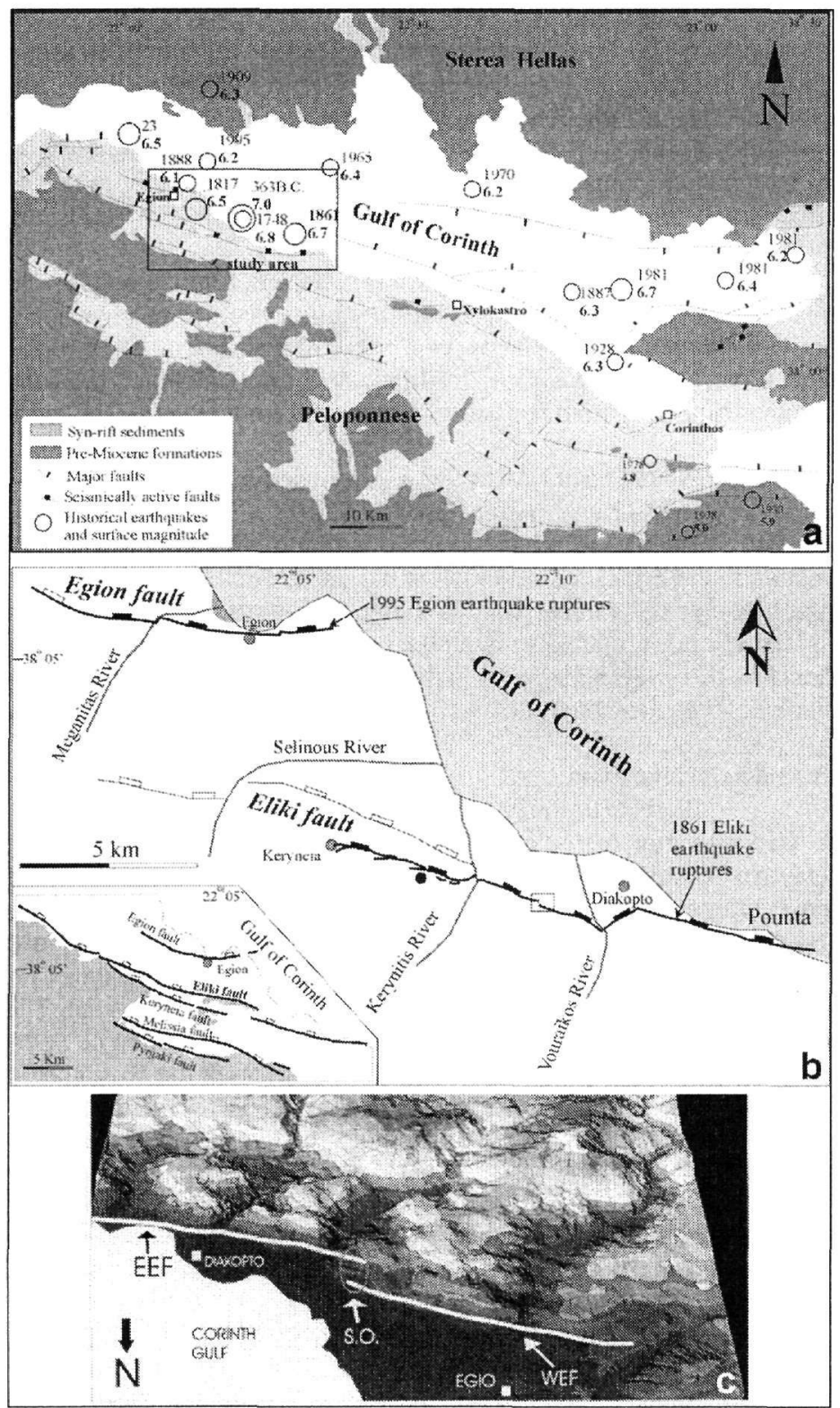

Figure 1. (a). Simplified seismotectonic map of the Gulf of Corinth showing active faults and historical earthquakes (after Koukouvelas \& Doutsos 1996). (b). The main tectonic features of the Egion - Diakopto area (after Koukouvelas et al. 2001). (c). The Eliki fault zone. EEF: East Eliki Fault, WEF: West Eliki Fault and S.O. : stepover zone. 


\section{METHODOLOGY}

Geomorphic evaluation of active tectonics depends on the use of geomorphic indices, which relate the sensitivity to rock resistance, climatic change and tectonic processes with the production of a certain landscape. The most widely spread geomorphic indices associated with fluvial systems are the mountain front sinuosity (Smf index; Bull \& McFadden 1977), the valley floor width to valley height ratio (Vf index; Bull 1977a, 1978), the stream gradient index (SL index; Hack 1973) and the transverse topographic symmetry factor (T index; Cox 1994).

Mountain front sinuosity (Smf) is defined as:

$$
\mathrm{Smf}=\mathrm{Lmf} / \mathrm{Ls}
$$

, where Smf is the mountain front sinuosity, Lmf is the length of the mountain front along the foot of the mountain and Ls is the straight - line length of the mountain front (Bull \& McFadden 1977, Keller \& Pinter 2001). This index reflects the balance between erosion that tends to produce irregular or sinuous fronts and tectonic forces that tend to create a straight mountain front coincident with an active range-bounding fault. In this study mountain fronts are defined as major fault bounded topographic range fronts with measurable relief exceeding two contour intervals $(20 \mathrm{~m})$ in 1:5000 maps, which is the working scale used.

Values of Smf approach 1.0 on the most tectonically active fronts, whereas Smf increases if the rate of uplift is reduced and erosional processes begin to form a front that becomes more irregular with time. Smf values lower than 1.4 indicate tectonically active fronts (Rockwell et al. 1984, Keller 1986) while higher Smf values ( $>3$ ) are normally associated with inactive fronts in which the initial range-front fault may be more than $1 \mathrm{Km}$ away from the present erosional front (Bull \& McFadden 1977).

The ratio of the width of valley floor to valley height (Vf) may be expressed by:

$$
V f=2 V f w /[(E l d-E s c)+(E r d-E s c)]
$$

, where Vfw is the width of valley floor, Eld and Erd are the elevations of the left and right valley divides respectively looking downstream and Esc is the elevation of the valley floor (Bull \& McFadden 1977). Comparison of the width of the floor of a valley with its mean height provides an index that indicates whether the stream is actively down cutting or is primarily eroding laterally into the adjacent hillslopes. The index reflects in this way differences between broad -floored canyons (Ushaped) with relatively high values of $\mathrm{Vf}$ and $\mathrm{V}$-shaped canyons with relatively lower values (Keller 1986).

The stream length gradient index is defined as:

$$
\mathrm{SL}=(\Delta \mathrm{H} / \Delta \mathrm{L}) \mathrm{L}
$$

, where $S L$ is the stream length gradient index, $\Delta H / \Delta L$ is the stream gradient at a specific site in the channel $(\Delta H$ is the change in elevation of the reach and $\Delta L$ is the length of the reach) and $L$ is the total channel length from the point of interest where the index is being calculated upstream to the highest point on the channel (Hack 1973, Keller \& Pinter 2001). The SL index is roughly related to the stream power while is particularly sensitive to changes in slope and lithology and this sensitivity allows the evaluation of the relationship between possible tectonic activity and rock resistance. This means that values of the index are high in areas where the rocks are significantly resistant or where active tectonics is present. Therefore, anomalously high SL values or fluctuation of the SL values in rock of uniform resistance is a possible indicator of active tectonics (Keller 1986).

Another quantitative index is the transverse topographic symmetry factor $(T)$, which is calculated from the equation:

$$
T=\mathrm{Da} / \mathrm{Dd}
$$

, where $\mathrm{Da}$ is the distance from the midline of the drainage basin to the midline of the active meander belt and Dd is the distance from the midline to the basin divide (Cox 1994). For a perfectly symmetric basin $T=0$ while $T$ increases and approaches a value of 1.0 as asymmetry increases. Values of $T$ are calculated for different segments of valleys and indicate preferred migration of streams perpendicular to the drainage basin axis (Keller \& Pinter 2001).

For the calculation of the above-mentioned geomorphic indices we used topographic maps at scale 1:5000 as well as aerial photographs of the study area. Fieldwork was also significant because details such as rock resistance or the propagation of each fault segment were precisely described and mapped. 
Many rivers of the Egion - Diakopto area can be classified as alluvial rivers according to Schumm's (1986) subdivision of river systems. Such rivers are sensitive to long term and earthquake-related deformation that modifies both the river profile and course. It has been proved by structural and morphological data that the courses of Meganitas, Selinountas, Kerynites and Vouraikos rivers have been controlled by the Eliki fault, changing their downstream profile towards the fault trace (Fig. 2; Koukouvelas 1998a, Koukouvelas 1998b, Pavlides et al. 2004). Over the footwall area of the west and east Eliki faults, and between these rivers, there are about 60 smallscale streams with lengths ranging from $50 \mathrm{~m}$ to $2 \mathrm{Km}$. On these ephemeral streams that cross the Eliki fault zone at high angles the values of the four geomorphic indices (Smf, Vf, SL, T) were estimated.

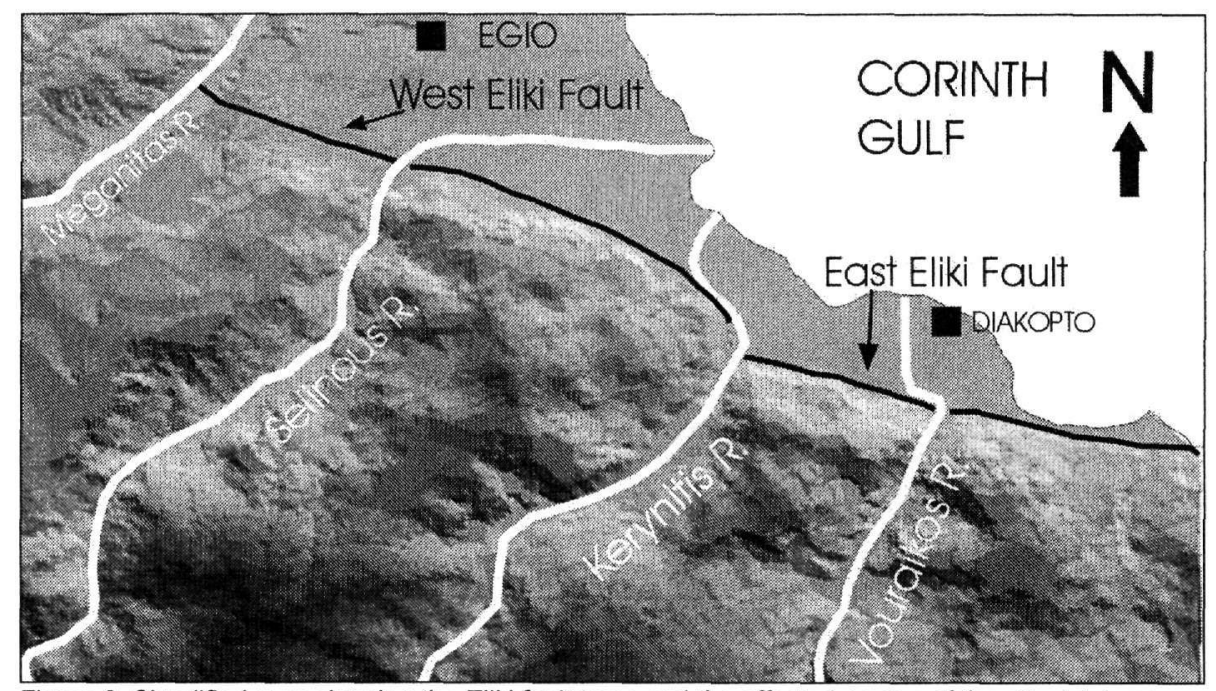

Figure 2. Simplified map showing the Eliki fault trace and the affected course of the alluvial rivers.

The application of the Smf index was utilized in three discrete segments of the fault with similar geological and morphological characteristics, the western, the eastern and the step-over zone. For the separation the following criteria were applied (Wells et al. 1988): a) intersection with large in scale cross - cutting drainage, relative to the front, b) abrupt changes in lithology (as it occurs in the western and eastern segments), c) changes in mountain front orientation (as in the case of the step over zone).

According to this separation the Smf index displays values close to 1.0 for the eastern segment and the step over zone (1.09 and 1.16 respectively) and a value slightly higher for the western segment (1.34). So it is obvious that Smf index takes values lower than 1.5 along the three segments of the Eliki fault, which is characteristic of tectonically active fronts (Keller \& Pinter 2001).

The impact of the Eliki fault on these small-scale streams draining the fault scarp is best defined by the Vf index calculation. We applied this index at a set distance from the mountain front (50m) for every studied valley. The reason for working in this way is that valley floors tend to become gradually narrower upstream from the mountain front. However, in certain valleys with a higher degree of interest (bigger stream power, changes in lithology, dramatically low or high values) we extend this analysis downstream from the mountain front. This fact enabled us to make sure that downstream from the mountain front $\mathrm{Vf}$ index displays only high values regardless of the lithology or the stream power. Vf values may also vary widely among streams with different drainage basin areas, discharges and bedrock lithologies. Consequently, Vf values were determined along the lengths of the streams (every $20 \mathrm{~m}$ ) in each segment with similar geological and morphological characteristics. 
The Vf values in the area range from 0.04 to 6.0 but for the needs of this study we came along with a mean Vf value for every valley. Comparing the values of the Vf index along and across the three segments of the Eliki fault zone it is noticed that Vf index displays high values $(0.34-3.5)$ along the western segment (Fig. 3a, C) whereas along the eastern segment and the step-over zone the $\mathrm{Vf}$ values range from 0.09 to 1.0 (Fig. $3 \mathrm{~b}, \mathrm{c}$ ). In more detail, mean Vf values display an increasing trend from east to west along the west Eliki fault (Fig. 3a), while along the east Eliki fault, mean Vf values show remarkable variations but without exceeding the value of 1 (Fig. $3 \mathrm{~b}$ ). The most interesting feature in the figure $3 \mathrm{~b}$ (between $10-12 \mathrm{Km}$ of the east Eliki fault) is the step-over zone that demonstrates extremely low Vf values. This fact marks out that the tectonic activity is higher at the step over zone than anywhere else and shows that the junction area between the two segments is actually the most promising. Also across the three segments the $\mathrm{Vf}$ ratio indicates low values close to the range front and higher values at the southern fault strand, which is defined as the headwater area of the streams (Fig. 4a).

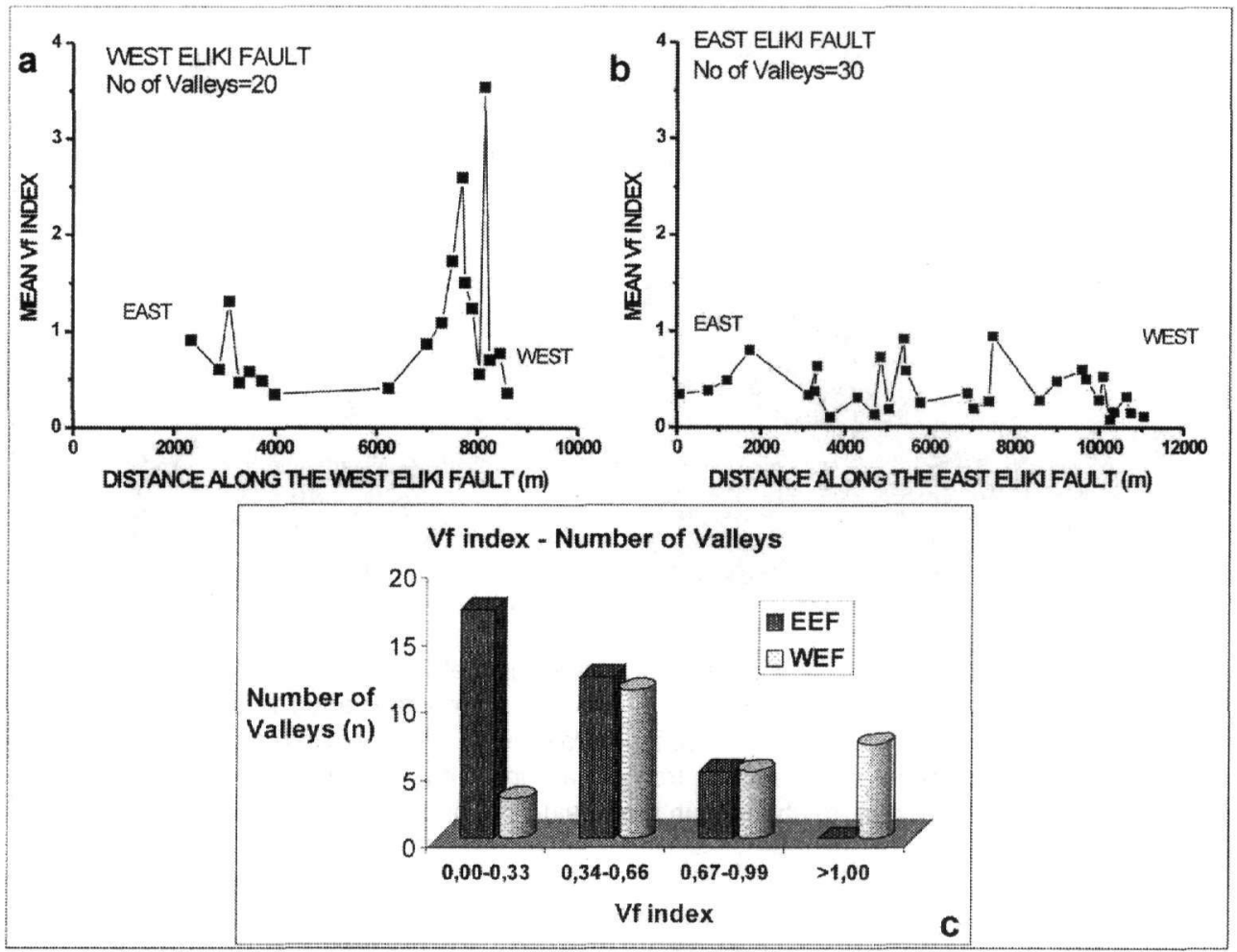

Figure 3. (a, b). Plots of distance along WEF and EEF vs. Vf. The (b) plot includes also the distribution of the Vf values of the step over zone between $10-12 \mathrm{Km}$. (c). Diagram showing the distribution of $\mathrm{Vf}$ values in East Eliki fault (EEF) and in West Eliki fault (WEF). In the EEF the values of the step over zone are also included.

However, over the footwall area of the western segment the effect of uplift does not seem significant for a large area behind the active front (less than 200m) (Fig. 4b), while this effect is obviously present for almost $1 \mathrm{Km}$ behind the active front over the eastern segment (Fig. 4c). These observations in general are representative of an active tectonic area. Still the eastern segment and the step over zone reflect $\mathrm{V}$ - shaped valleys with streams that are actively incising (low Vf values) while at the western segment the tectonic activity becomes less vigorous with a clear tendency of prevalence of $\mathrm{U}$ - shaped valleys (high Vf values). 


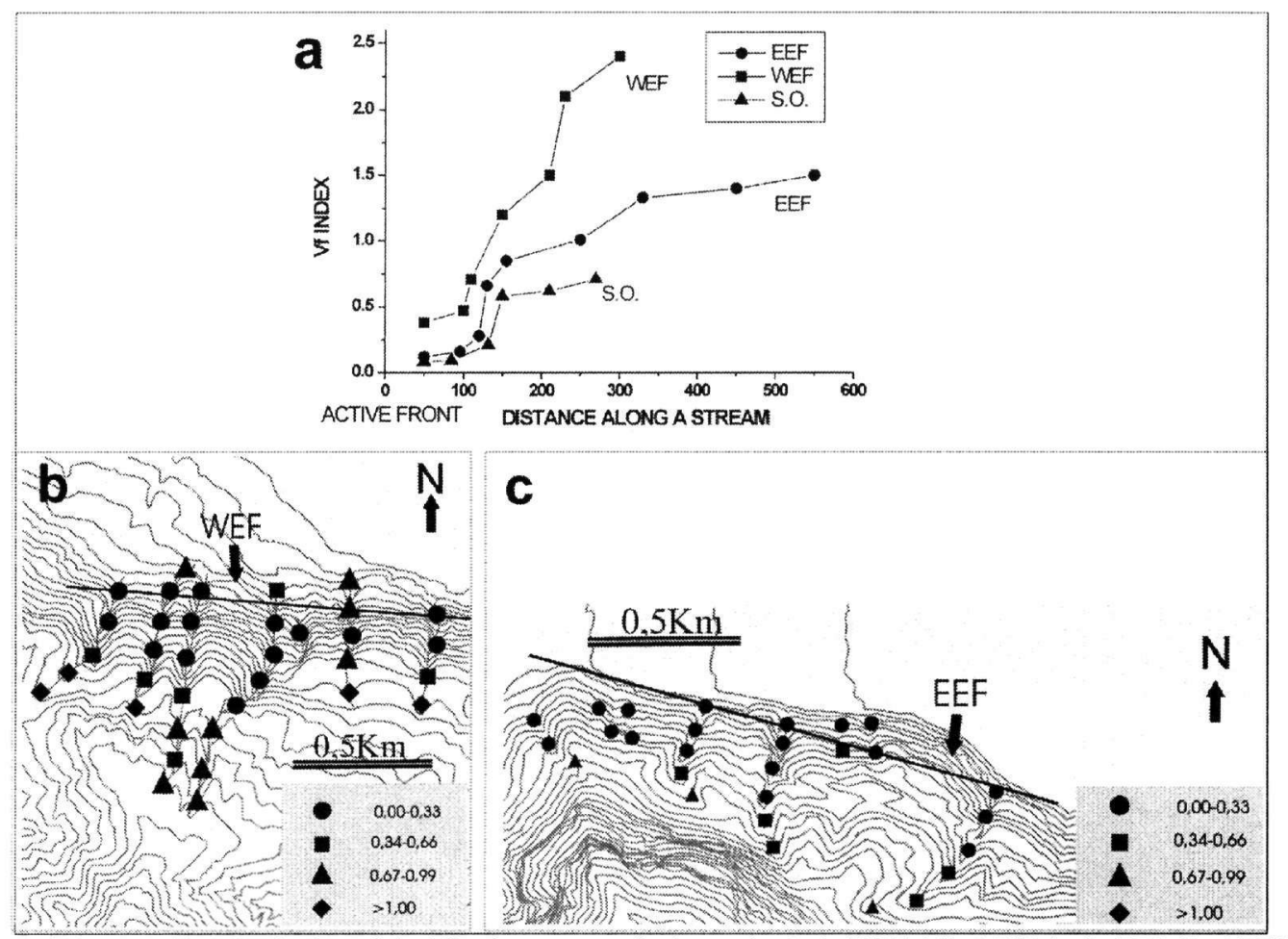

Figure 4. (a). The distribution of the Vf values perpendicular to the fault (WEF: West Eliki fault, EEF: East Eliki fault, S.O.: step over zone). (b, c). Schematic presentations of the distribution of $\mathrm{Vf}$ values along and across the West Eliki fault (WEF) and the East Eliki fault (EEF).

The same results seem to be extracted by the analysis of the SL index too. Most sensitive to tectonics are the first order streams because it is evident that larger streams have sufficient stream power to overwhelm the effects of tectonics so we applied this index only on small-scale streams. The values of SL index along the Eliki fault are mainly low, ranging from $0-300$ gradient meters (Fig. $5 a, b$ ). As it is described in the figure $5 a, b$, there is a general decreasing trend towards the west for mean SL values along the west and east Eliki fault. However, this trend is affected by the existence of the step over zone, located at the western end of the east Eliki fault (between 10 $12 \mathrm{Km}$ ), which exhibits remarkable higher mean Vf values (Fig. $5 \mathrm{~b}$ ). This observation along with the bend of Kerynites river course towards the step over zone (Pavlides et al. 2004) shows that this zone concentrates the site with higher tectonic activity within the Eliki fault zone. Taking into account that the majority of the streams at both segments are small it seems that the length of the streams is the main reason responsible for the domination of the low mean SL values. So the variety of values becomes the determinative factor showing the existence of tectonic effect. Unlike the distribution of $\mathrm{Vf}$ values $\mathrm{SL}$ index obtain high values near the active front and low values rear from the front (Fig. 5c). However, the lack of important fluctuations of the SL index across the western segment, highlights the domination of the fluvial processes over the tectonic activity (Fig. $5 \mathrm{~d}$ ), while at the same time the eastern Eliki segment and the step over zone illustrate anomalous variations of the SL index which are due to the increasing tectonic activity or to the presence of rocks with low resistance to erosional processes (Fig. 5d, e). Especially the step over zone indicates a significant number of SL irregularities across its streams, so it is obvious that there are at least two small scale synthetic faults inside this zone. Overall, these variations suggest that tectonic activity along the Eliki fault and the step over zone is not bounded along the range fault strand but imply a broader tectonically uplifted active area. 


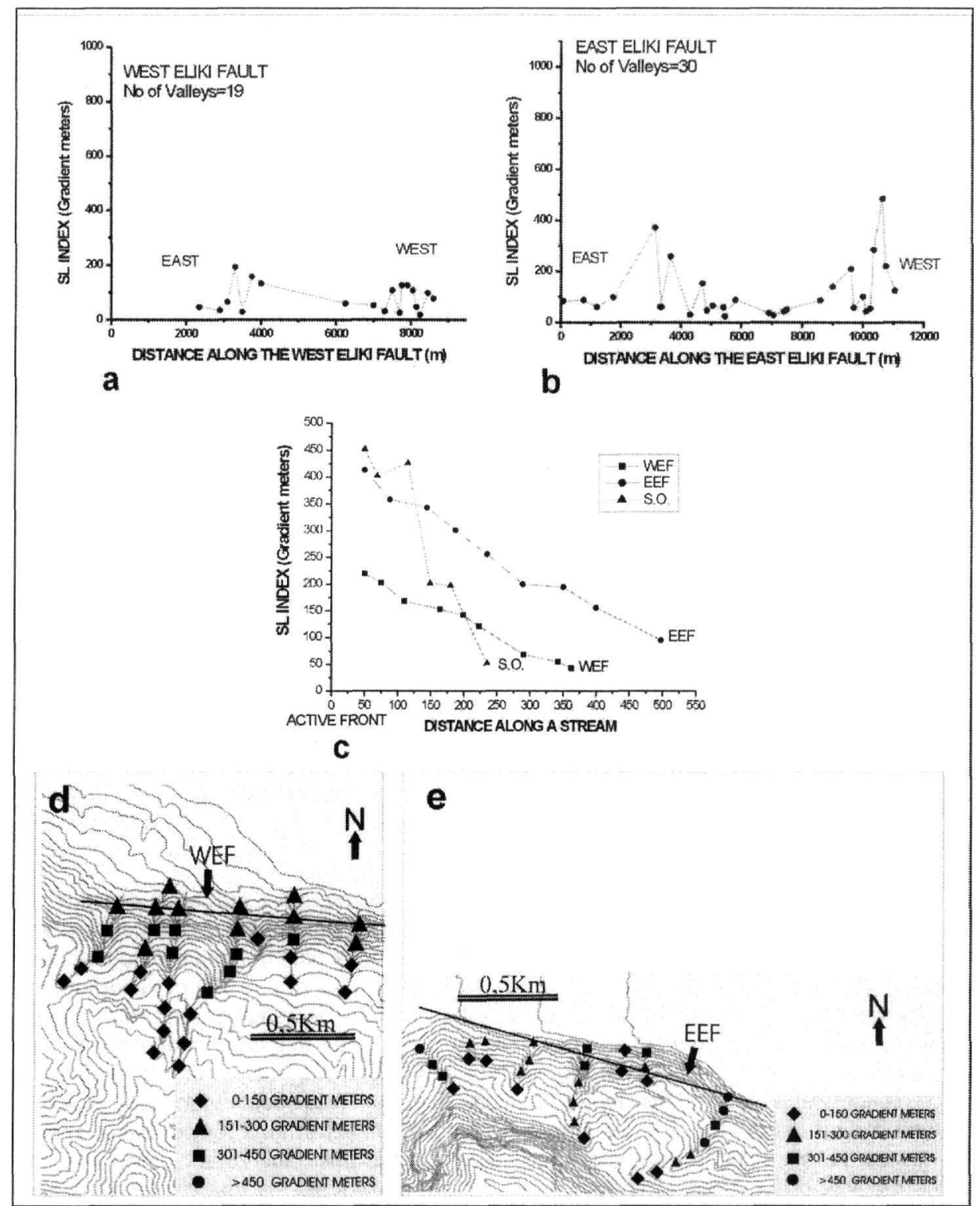

Figure 5. (a, b). Diagrams showing the distribution of SL values along the West Eliki fault and the East Eliki fault. Between $10-12 \mathrm{Km}$ the values of SL index correspond to the streams of the step over zone. (c). The distribution of the SL values perpendicular to the fault (WEF: West Eliki fault, EEF: East Eliki fault, S.O.: step over zone). (d, e). Schematic presentations of the distribution of SL values along and across the West Eliki fault (WEF) and the East Eliki fault (EEF).

Furthermore, the estimation of the drainage basin symmetry using the Transverse Topographic Symmetry Factor $(T)$ shows that the majority of the streams which shift towards the fault appear to be slightly asymmetric since the $50 \%$ and the $80 \%$ of the valleys of the west Eliki fault and the east Eliki fault, respectively, belong in the class $0-0.5$ (Fig. 6) In general the calculated $T$ values vary from 0.04 (almost symmetric) to 0.74 (roughly asymmetric). This index is not considered as objective enough because the exact response to the asymmetry factor and the needed time to achieve this asymmetry is not thoroughly investigated. 

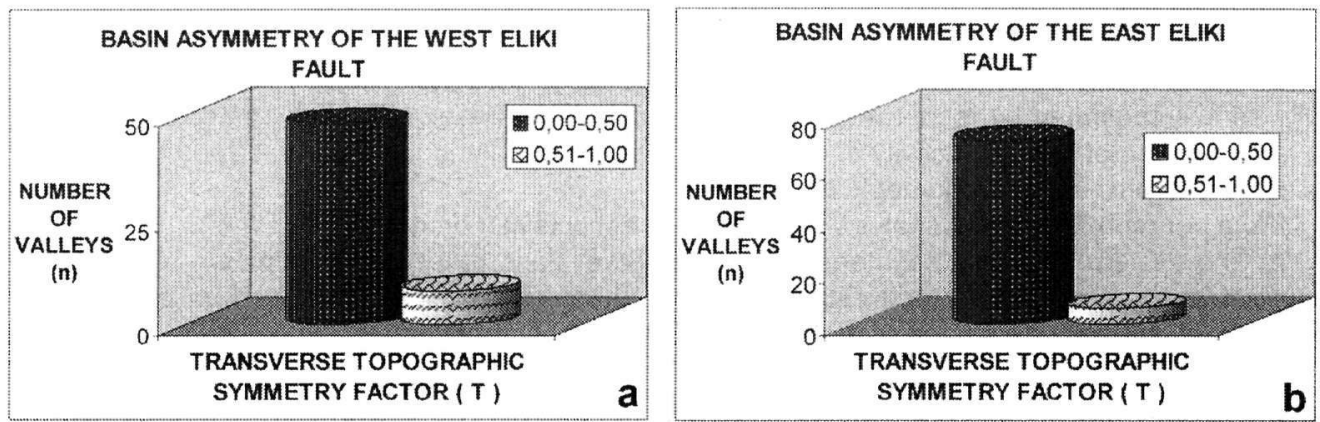

Figure 6. (a, b). Statistical diagram showing the distribution of $T$ values in every segment. The (b) diagram also includes the $T$ values of the step over zone.

Finally, we tried to correlate the Smf and Vf index since it has been proved that the combination of the $\mathrm{Smf}$ and $\mathrm{Vf}$ indexes can provide quantitative information of the relative degree of tectonic activity of the segmented fault zone and allows individual mountain fronts to be assigned in different tectonic activity classes. (Fig. 7a; Rockwell et al. 1984, Bull \& McFadden 1977, Keller \& Pinter 1996, Silva et al. 2003). The Smf and mean Vf values of the western, eastern and step-over mountain fronts, along with the standard deviations $\left(\sigma_{n-1}\right)$ of the Vf values, are shown on a diagram Smf vs Vf, depicting one group of values (Fig. $7 \mathrm{~b}$ ). This group can be assigned to the first tectonic class according to the division suggested by Keller \& Pinter (2001). The first tectonic class comprises values of Smf lower than 1.5 and Vf values lower than 1.2. As it is easily noticed the western front displays relative higher Smf and Vf values, compared to the other two mountain fronts, although it is projected inside the first tectonic class. This observation along with the fact that during the 1861 A.D. seismic event only the eastern Eliki fault segment was ruptured indicates a gradually decreasing tectonic activity towards the west.

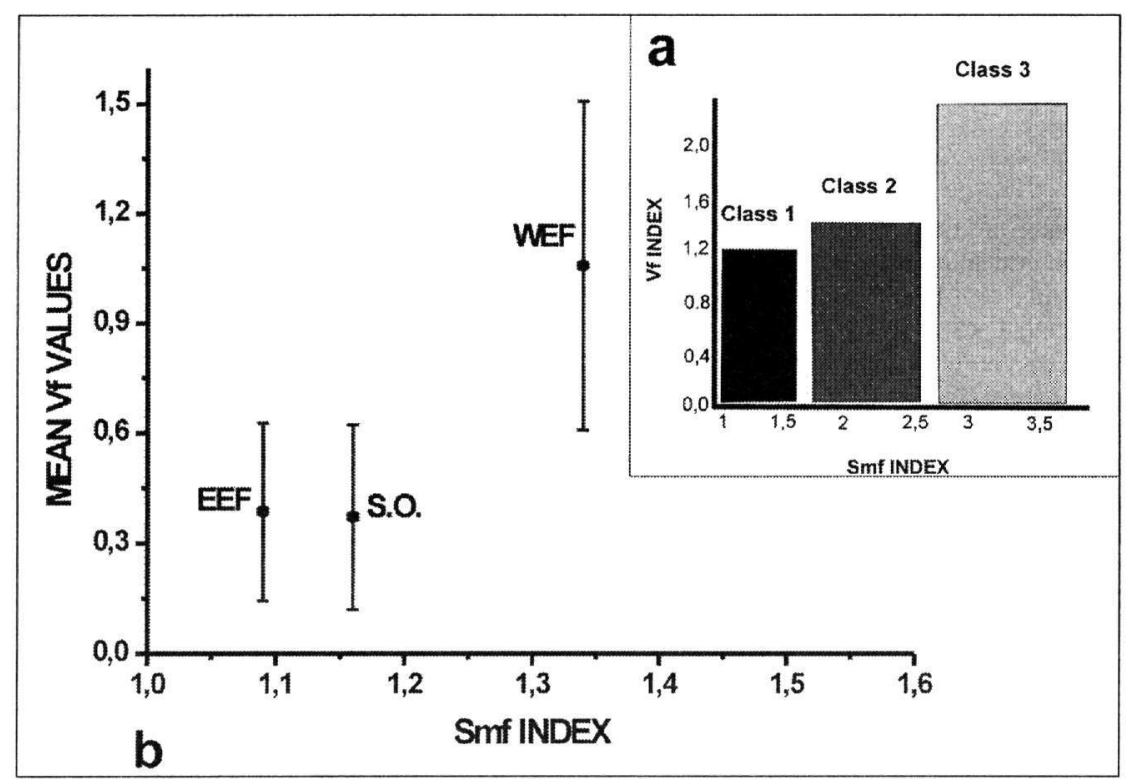

Figure 7. (a). Schematic presentation of the Keller and Pinter's division of tectonic activity. (b). Plot of Smf vs. Vf of the East Eliki Fault (EEF), the West Eliki Fault (WEF) and the step-over zone (S.O.). Vertical bars show the standard deviation for Vf values in every front. 


\section{CONCLUSIONS}

Eliki fault is a complex normal fault showing a composite fault scarp and continuous tectonic activity as it is confirmed by recent well-documented paleoseismological studies and seismic events. Spatial variation of tectonic activity of different fault segments along the Eliki fault zone is assessed using geomorphic and morphometric approaches.

From our morphotectonic analysis some interest aspects can be drown:

a) The eastern Eliki fault segment and the step over zone reflect the domination of V-shaped valleys with streams that are actively incising (low Vf values) over the U-shaped valleys (high Vf values) that characterize a large part of the west Eliki fault segment.

b) Across the western and eastern Eliki fault segments tectonic activity concentrates along the range front fault strand according to the distribution of the Vf and SL values. At the same time the low Vf values and the fluctuations of the SL values, which possess a wide area behind the eastern front, indicate that the effect of the tectonic uplift is obviously present for almost $1 \mathrm{Km}$ behind the active front and diminishes at $200 \mathrm{~m}$ behind the western active front. The combined morphometric data suggest a general pattern of localized higher activity on the eastern terminations of the segmented fronts.

c) In general, morphotectonic analysis, based on the correlation of the Smf and Vf index, illuminate that all Eliki fault segments and the step-over zone display relatively high activity and they can be assigned to the first tectonic class (sensu Keller and Pinter 2001; Silva et al. 2003). However, spatial variations of tectonic activity along the studied fronts point to a general trend of increasing activity towards the east. This observation along with the fact that during the 1861 A.D. seismic event only the eastern Eliki fault segment was ruptured indicates a gradually decreasing tectonic activity towards the west. Morphometric data combined with seismic and geomorphic data seems to be a valuable tool in determining relative levels of tectonic activity and in providing data for seismic hazard assessment.

\section{ACKNOWLEDGEMENTS}

The authors would like to thank I. Koukouvelas for his comments and suggestions during the realization of this study.

\section{REFERENCES}

Ambrasseys N. N., Jackson J. 1990. Seismicity and associated strain of central Greece between 1890 and 1988. Geophysical Journal International 101, $663-708$.

Ambrasseys N.N., Jackson J. 1997. Seismicity and strain in the Gulf of Corinth (Greece) since 1694. Journal of Earthquake Engineering 1, 433-474.

Bull W. 1977a. Tectonic geomorphology of the Mojave Desert. U.S. Geol. Surv. Contact Rep. 14-08-001-G394, Office of Earthquakes, Volcanoes and Engineering, Menlo Park, Calif., 188.

Bull W. 1978. Geomorphic tectonic activity classes of the south front of the San Gabriel Mountains, California. U. S. Geol. Surv. Contact Rep. 14-08-001-G-394, Office of Earthquakes, Volcanoes and Engineering, Menlo Park, Calif., 59.

Bull W., and McFadden L., 1977. Tectonic geomorphology north and south of the Garlock Fault, California, Geomorphology in Arid regions, D. O. Doehring, ed., Publications in Geomorphology, State University of New York at Bingamton, $115-138$.

Burbank D. W., Anderson R. S., 2001. Tectonic geomorphology. Blackwell Science, USA, 274.

Clarke P. J., Davies R. R., England P. C., Parsons B. E., Billiris H., Paradissis D., Veis G., Denys P. H., Cross P. A., Askenazi V., Bingley R., 1997. Geodetic estimate of seismic hazard in the Gulf of Korinthos. Geophysic. Res. Lett. 24, $1303-1306$.

Cox R.T. 1994. Analysis of drainage basin symmetry as a rapid technique to identify areas of possible quaternary tilt block tectonics: an example from the Mississippi embayment. Geol. Soc. Am. Bull. 106, $571-581$.

Doutsos T., Piper D. J. W., 1990. Listric faulting, sedimentation and morphological evolution of the quaternary eastern Corinth rift, Greece: first stages of continental rifting. Bull. Geol. Soc. Am. 102, 812 - 829.

Doutsos T., and Poulimenos G., 1992. Geometry and kinematics of active faults and their seismotectonic significance in the western Corinth - Patras rift (Greece). Journal of Structural Geology 14, 689-699. 
Doutsos T., Kokkalas S., 2001. Stress and deformation patterns in the Aegean region. Journal of Structural Geology $23,455-472$.

Hack J., 1973. Stream profile analysis and stream gradient index, U. S. Geol. Surv. J. Res. 1, $421-429$.

Jackson J. A. Gagnepain J., Houseman G., King G. C. P., Papadimitriou P., Soufleris C., Vireux J., 1982. Seismicity, normal faulting, and the geomorphological development of the Gulf of Corinth (Greece): the Corinth earthquakes of February and March 1981. Earth and Planetary Science Letters 57, 377 - 397.

Jackson J. A., McKenzie D. P., 1988. Rates of active deformation in the Aegean Sea and surrounding areas. Basin Research 1, $121-128$.

Jackson J. A., 1994. Active tectonics of the Aegean region. Annual review of Earth and Planetary Science Letters22, $239-271$.

Keller E., 1986. Investigation of active tectonics: use of surficial earth processes. In: Wallace, R. E. (eds), Active Tectonics studies in Geophysics. Nat. Acad. Press, Washington, Dc, 136 - 147.

Keller E., and Pinter, N., 2001. Active Tectonics, Earthquakes, Uplift and Landscape, Earth Sciences Series, Prentice - Hall, Englewood Cliffs, NJ.

King G. C. P., Ouyang Z. X., Papadimitriou P., Deschamps A., Gagnepain, L., Houseman G., Jackson J. A., Soufleris C., Virieux J., 1985. The evolution of the Gulf of Corinth (Greece): an aftershock study of the 1981 earthquakes. Geophysical Journal, Royal Astronomical Society 80, $677-693$.

Koukouvelas I. K., 1998a. Transfer zones along active normal faults in Peloponnesus, Greece. Bull. Geol. Soc. Greece 32, $221-229$.

Koukouvelas I. K., 1998b. The Egion fault, earthquake - related and long - term deformation, Gulf of Corinth, Greece. Journal of Geodynamics 26, $501-513$.

Koukouvelas I., Stamatopoulos L., Katsonopoulou D., and Pavlides S., 2001. A paleoseismological and geoarchaeological investigation of Eliki fault, Gulf of Corinth, Greece, Journal of Structural Geology 23, $531-543$.

Le Pichon X., Angelier J., 1981. The Aegean Sea. Philosophical Transactions of the Royal Society of London $300,357-372$.

McKenzie D. P., 1978. Active tectonics of the Alpine - Himalayan belt: the Aegean Sea and surrounding regions. Geophysical Journal of the Royal Astronomical Society 55, $217-254$.

Papazachos B. C., Papazachou C., 1997. The earthquakes of Greece. Ziti, Thessaloniki, 304.

Pavlides S., Koukouvelas I., Kokkalas S., Stamatopoulos L., Keramydas D., and Tsodoulos I., 2004. Late Holocene evolution of the East Eliki fault, Gulf of Corinth (Central Greece), Quaternary International, 115 - 116, $139-154$.

Piper D. J. W., Stamatopoulos L., Poulimenos G., Doutsos T., Kontopoulos N., 1990. Quaternary history of the Gulfs of Patras and Corinth, Greece. Zeitschrift fur Geomorphologie 34, 451 - 458.

Poulimenos G., Doutsos T., 1996. Barriers on seismogenic faults in central Greece. J. Geodynamics 22, $119-$ 135.

Roberts G. P., Koukouvelas I. K., 1996. Structural and seismological segmentation of the Gulf of Corinth fault system: implication for models of fault growth. Annali di Geophysica 39, 619-646.

Rockwell T., Keller E., Johnson D., 1984. Tectonic geomorphology of alluvial fans and mountain fronts near Ventura, California. In: Morisawa, M., Hack T. J. (eds), Tectonic Geomorphology. Publ. In Geomorphology, State University of new York, Binghamton, $183-207$.

Schumm S. A., 1986. Alluvial river response to active tectonics. In: Active Tectonics, Studies in Geophysics. National Academy Press, Washington DC, $80-94$.

Silva P., Goy J., Zazo C., Bardaji T., 2003. Fault - generated mountain fronts in southeast Spain: geomorphologic assessment of tectonic and seismic activity. Geomorphology 50, 203-225.

Wells S. G., Bullard T. F., Menges C. M., Drake P.G., Karas P. A., Kelson K. I., Ritter J. B., Wesling J. R., 1988. Regional variations in tectonic geomorphology along a segmented convergent plate boundary, Pacific coast of Costa Rica. Geomorphology 1, 239-265. 